Rütten, A., Lüschen, G., Lengerke, T. von, Abel, T., Kannas, L., Rodrígue Diaz, J.A., Vinck, J., Zee, J. van der Determinants of health policy impact: a theoretical framework for policy analysis.

Sozial- und Präventivmedizin: 48, 2003, nr. 5, p. 293-300

\begin{tabular}{|l|l|}
\hline Postprint Version & 1.0 \\
\hline Journal website & $\underline{\text { http://www.springerlink.com/content/109374/ }}$ \\
Pubmed link & $\begin{array}{l}\text { http://www.ncbi.nlm.nih.gov/entrez/query.fcgi?.cmd=Retrieve\&db=pubmed\&dop } \\
\text { t=Abstract\&list_uids=14626621\&query_hl=88\&itool=pubmed_docsum }\end{array}$ \\
\hline DOI & $\underline{10.1007 / \text { s00038-003-2118-3 }}$
\end{tabular}

Soz.- Präventivmed. 48 (2003) 293-300

0303-8408/03/050293-08

DOI 10.1007/s00038-003-2118-3

(C) Birkhäuser Verlag, Basel, 2003

1 Friedrich-Alexander-University of Erlangen-Nuremberg

2 University of Illinois at Urbana-Champaign, (em.)

3 GSF-National Research Center for Environment and Health, Neuherberg

4 University of Berne

5 University of Jyväskylä

6 University of Barcelona

7 Limburg University Centre, Diepenbeek

8 Netherlands Institute of Health Services Research, Utrecht

\title{
Determinants of health policy impact: a theoretical framework for policy analysis
}

\begin{abstract}
SUMMARY
This paper addresses the role of policy and evidence in health promotion. The concept of von Wright's "logic of events" is introduced and applied to health policy impact analysis. According to von Wright (1976), human action can be explained by a restricted number of determinants: wants, abilities, duties, and opportunities. The dynamics of action result from changes in opportunities (logic of events). Applied to the policymaking process, the present model explains personal wants as subordinated to political goals. Abilities of individual policy makers are part of organisational resources. Also, personal duties are subordinated to institutional obligations. Opportunities are mainly related to political context and public support. The present analysis suggests that policy determinants such as concrete goals, sufficient resources and public support may be crucial for achieving an intended behaviour change on the population level, while other policy determinants, e.g., personal commitment and organisational capacities, may especially relate to the policy implementation process. The paper concludes by indicating ways in which future research using this theoretical framework might contribute to health promotion practice for improved health outcomes across populations.
\end{abstract}

Health policy is currently put to the test. Given growing costs and budgetary deficits, health impact assessment and cost-benefit-analysis of different health policy approaches became crucial issues for health system reforms in many countries. In this context, both experts and policymakers again and again stress the limited advances offered through medical care, and emphasise the importance of prevention and health promotion policies. Paradoxically, however, so far in most countries only limited efforts have been made to implement such policies. For example, in Germany in the year 2000 merely $4.5 \%$ of the total expenditures on health were spent on prevention and health promotion (Federal Statistical Office Germany 2002). One crucial point in the debate on allocating more resources to this area of health policy is the evidence base of health promotion and related policies. In other words: In what ways does health policy contribute to promoting the health of the population? How effective are different health policy approaches in this regard? 
Rütten, A., Lüschen, G., Lengerke, T. von, Abel, T., Kannas, L., Rodrígue Diaz, J.A., Vinck, J., Zee, J. van der Determinants of health policy impact: a theoretical framework for policy analysis.

Sozial- und Präventivmedizin: 48, 2003, nr. 5, p. 293-300

To start with the latter question, several case studies have demonstrated the effectiveness of very distinct policies in approaching health risk factors and promoting the health of the population. For example, policies on breast cancer screening have been implemented in many countries (Shapiro et al. 1998) and have been shown to result in reduced mortality from breast cancer (Advisory Committee on Cancer Prevention of the EU 2000). Protection and prevention policies against smoking (WHO 1998) provide another example of effectively approaching health behaviour of populations (Brownson et al. 1995). Case studies also demonstrated that the very complex concept of healthy public policy as defined in the Ottawa Charter of Health Promotion (WHO 1986) can be implemented and provide a very evident strategy to create better conditions for health (Rootman et al. 2001).

Turning to the question of how health policy contributes to promoting the health of populations, however, a fundamental problem is that even when there is a scientifically credible evidence base for a health promotion policy, it is rather unclear if this evidence is effectively used by policymakers to develop health policy. For example, in contrast to other EUcountries the federal government of Germany neither supports approaches to ban smoking advertisement, nor does it promote physical activity programs. What are the reasons for such differences in health policies between European countries - just lack of evidence, or more likely particular determinants within the policymaking process, e.g., lack of resources and organisational capacity or divergent policy goals and obligations? From the health promotion viewpoint, there is a lack of knowledge on the politics of policymaking and implementation. It is this issue that this article and a subsequent research paper (Rütten et al. 2003) address. Both focus on outlining major political determinants of health policy implementation and health policy impact. The rationale for the two papers is to contribute to building the framework and the evidence base for effective health promotion policy development, implementation, and evaluation.

The general theoretical perspective offered in this article can be placed in the context of existing policy-related theory in health promotion research. For example, Milio (1981: 69) dealt with both health policy and health-related action of the population by stressing that "healthful lifestyles are not a matter of 'free' choice, but rather the result of opportunities available to people, and that policy affects those opportunities”. She also presented an ecological concept for policy studies (Milio 1988) and, more recently, a framework relating policy environment and policy impact (Milio 1998), which include some of the elements discussed below. In particular, Milio's approaches focus on organisational and public opportunities for health policymaking. With regard to the latter, she emphasises adequate information strategies and the role of mass media in shaping public support for policy development (Milio 1998).

Following Milio's perspective on the interplay between policymakers, interest groups, public support, and media, de Leeuw (1989) employed the theory of agenda building (Cobb \& Elder 1983) to investigate the different factors bringing about health policy in The Netherlands. In this context, results are especially relevant regarding the feasibility of what she referred to as "health policy", i.e., healthy public policy (de Leeuw \& Polman 1995: 331). For example, perceived problems of interest groups in further development of "health policy" are mainly related to "general vagueness" (see below "concreteness of goals"), "financial prerequisites” (see below "resources”), "social incompabilities" (see below "obligations") and "lack of political will" and "structure governmental bureaucracy" (see below "opportunities”).

Regarding the latter point of political opportunities, also the issue of the ideological underpinnings of health policymaking, i.e., the importance of political parties and the policies they implement when in government, has been raised in the context of health policy impact analysis (Navarro \& Shi 2001).

Within the broader context of public health research, this article introduces a theoretical perspective not widely known in health science literature to approach specific challenges of contemporary health policy analysis, and to overcome some deficiencies of previous research:

1. Existing research rarely goes beyond descriptive accounts, if the matter is policy process and health impact analysis. While there are a number of in-depth structural analyses of existing welfare and health policies on the basis of aggregate data (Alber \& Bernardi-Schenkluhn 1992; Esping-Andersen 1990; Pampel \& Williamson 1989) or qualitative approaches (de Swaan 1988), studies on process and evaluation of health policy from the perspective of those making and shaping policy (policymakers) as well as from the perspective of those upon whom policy is directed (population) are rare (Lüschen et al. 1995). 
Rütten, A., Lüschen, G., Lengerke, T. von, Abel, T., Kannas, L., Rodrígue Diaz, J.A., Vinck, J., Zee, J. van der Determinants of health policy impact: a theoretical framework for policy analysis.

Sozial- und Präventivmedizin: 48, 2003, nr. 5, p. 293-300

2. Recent research discussions in international perspective either concentrate on rather specific economic analysis of cost-effectiveness and health care policies (Drummond, Jönsson \& Rutten 1997; Drummond et al. 1997; Haddix et al. 1996; Phillips 1997; Reinhard 1997; Sloan \& Grabowski 1997), or they focus on evaluating "healthy public policies” in terms of comprehensive inter-sectoral action (Goumans \& Springett 1997; Nutbeam 1998; Rootman et al. 2001; Rütten 2001; Whitehead 1996; Ziglio et al. 2001). While the former runs the risk of inappropriately reducing the diversity of policy determinants, inviting criticism for its reduced focus on "people as means to the end of improved indicators" (Hammer \& Berman 1995), its "narrow view of political activity" (Melhaldo 1998: 251), or "the dangers of limited market perspectives in policy analysis" (Wilensky 1997: 1241), the latter has to struggle with the increasing complexity inherent to the health promotion concept as outlined in the Ottawa Charter of Health Promotion (WHO 1986; Rütten 1995).

3. Health policy research is confronted with specific methodological problems that are exacerbated when policies are analysed in an international perspective. For example, the "fuzziness" of health policy has been mentioned recently, and the "use of primary sources and expert consultation" recommended, in order to provide insights in "formal rules" and "initial intentions" of policy measures as well as for the "impact" of health policy reforms at the performance level (Kroneman \& van der Zee 1997). Obviously, there is considerable need for theory-driven approaches to guide policy and evaluation research especially under conditions of high complexity and “fuzziness” (Chen 1990; Dean 1996; McQueen 1996; Weiss 1995).

To conclude, a health policy evaluation methodology needs to be developed and put to an empirical test which (1) is guided by theory and has explanatory power, (2) addresses the complexity and accounts for the specificity of health policymaking processes but uses the most parsimonious model, and (3) enlightens the "black box" of the implementation process from policy formulation to policy outputs and outcomes for better explaining and understanding how key determinants of the policymaking process affect the health behaviour of the population.

The theoretical framework presented in this study uses von Wright's (1976) logical model of events and identifies four key determinants of health policy that are crucial for the structure of complex policy systems of action: (1) goals, (2) resources, (3) obligations, and (4) opportunities. While von Wright seemingly talks in a language that refers to an individual's intention, it is being assumed that a transfer to the structural level of a policy system is entirely in line with von Wright's theory. In this way it is opened up for its uses in policy analysis (Lüschen 1995) and integrates the distinction between the individual and structural level of action (Coleman 1990). ${ }^{1}$ In the subsequent paper (Rütten et al. 2003), empirical analyses will use data from a cross-national policymaker survey conducted in the frame of an international research project (MAREPS). In terms of policymakers' substantive knowledge and their competence in one of four selected policies, they are supposed to provide information on their experiences with regard to three main issues:

1. How do they evaluate the determinants for their policy?

2. How do they evaluate the impact of their policy?

3. How do they evaluate the impact of the policy in terms of policy determinants?

In sum, the overall purpose of the present paper is to specify key determinants of health policy that are by theory crucial for the structure and impact of health promotion policy, and to analyse their

\footnotetext{
${ }^{1}$ To opt for methodological individualism as the subsequent study does for data collection can well be justified in the analysis of policy processes. Policymakers are not only due to their efforts and failures part of the process, they are also highly sensitive about their experiences. Thus, in the following analysis they are not so much policy actors as they are experts. Yet, policymakers are individuals to only a limited degree. As occupants of specific positions they perform roles that leave them little opportunity and freedom. To use Dahrendorf's (1977) terms they have in their normative demands to fulfil muss- (must) and soll- (should) expectations. Their chance for creative, spontaneous action is low and this is so in particular in cultural systems that are much less individualistic than e.g. the American system is. Thus, what at first sight appears to be a study of individuals, is actually a study of policy systems that makes use of individual members for mainly heuristic purposes - methodological individualism. The actual interest of the analysis is in the structure of policy and system. Given these assumptions, items that are supposed to measure structural orientations and facts measure systemic qualities even if an item uses formulations like $I$ am satisfied with the results. Of course, the proof is in the pudding and the construction of indices in the subsequent research paper (Rütten et al. 2003) will show whether the assumption that operationalisations using the I-form measure the same or similar structures as those asking for an evaluation of system or organisational property is correct.
} 
Rütten, A., Lüschen, G., Lengerke, T. von, Abel, T., Kannas, L., Rodrígue Diaz, J.A., Vinck, J., Zee, J. van der Determinants of health policy impact: a theoretical framework for policy analysis.

Sozial- und Präventivmedizin: 48, 2003, nr. 5, p. 293-300

relationships with two impact dimensions (policy output and outcome). Empirical research and applied perspectives for the evaluation of prevention and health promotion derived from the results of a policymaker survey are presented and discussed in the subsequent paper (Rütten et al. 2003).

\section{Theoretical model of policy determinants}

The concept of the "logic of events" applied in the present paper was originally presented by von Wright (1976; see also Lüschen 1992; 1995). According to this concept, determinants of action can be shown to be logically consistent both in the natural and the social sciences. At the same time, however, determinism in the social sciences means "something utterly different from determinism in the study of nature” (von Wright 1976: 415). In the social sciences, determinants are not based on general laws of nature and their existence is not independent of human beings; they reflect institutionalised societal rules as historical results of human action. According to von Wright, these determinants have

"(...) their roots in the structure of the social fabric: in the distributions of roles and the institutionalization of behavior- patterns. With changes in these societal determinants of actions, actions too will be different. But changes in the determinants are in their turn the result of action - except for the cases when they are man-independent changes in nature. Thus the actions of men are determined by their historical situation, but the historical situation is itself the result of the actions of men.” (von Wright 1976: 435).

Von Wright's approach offers a general logic of action which can be used to analyse different types of actors on different levels of action: First, the approach is suitable to explain and understand actions on the health policy level. For example, it may explain why in one case public health agents shape a community health promotion policy according to the current evidence base provided by health promotion research while in another case this evidence is neglected because major determinants of policy implementation are negative (e.g., unclear goals, insufficient resources etc.). Second, the approach is suitable to explain health-related actions of the population level which health policy may intend to modify by preventive strategies and interventions. Again, in one case a health promotion intervention (e.g., a new physical activity promotion program) may lead to a health behaviour modification while in another case the program will be neglected because major determinants of behaviour modification are negative (e.g., lack of willingness or abilities). The basic assumptions of this approach seem to be compatible with diverse mediating concepts in the social sciences, e.g., the duality of macro- and micro-level (Coleman 1990), social structure and agency (Giddens 1979; Giddens 1984), and the synthesis of actor-oriented and institutional factors (Kiser \& Ostrom 1982).

\section{Logic of action}

According to von Wright (1976), human actions can be explained by a small number of general determinants: wants, abilities, duties, and opportunities. For example, the interplay of these determinants explains why, in one case, the combination of wanting to be healthy and knowing the healthy effects of swimming leads to an intention to go swimming, whereas, in another case, such an intention is not generated, because one has conflicting family duties (looking after children) or insufficient abilities (non-swimmer). Crucial for the dynamics of this interplay (see Fig. 1) is the constant change of external situations creating new opportunities, while wants, abilities, and especially duties as the internal determinants remain relatively stable, since they usually are integrated in fixed institutional arrangements. Thus, a singular situational change, for example a newly offered swimming course for parent and child, can (1) (re)create the intention to go swimming, since now one can act not only according to the latent want to be healthy, but (2) has the opportunity to broaden one's abilities (learn how to swim, or swim better), while (3) the intention is now compatible with the duty of looking after the children. The action of enrolling to the new swimming course (4) results from the "(...) interplay between situational change, intentionality, ability, and a motivational and normative background (...)" (von Wright 1976: 432). This interplay is termed by von Wright the "logic of events". By the concrete action, institutionalised action rules (e.g., formal enrolment procedures) are reproduced, while at the same time new situations are created, which, being opportunities, may trigger subsequent events.

\section{Context and level of action}


In its general form outlined above, the logic of events can be applied both to health-related behaviour of the population and to the health policy action of policymakers. A policymaker might, for example, relate to his election as mayor (new opportunities) the intention to implement swimming courses for parent and child, given that developing this new offer does not require additional resources (abilities), that it corresponds to his political goals (e.g., want to support families with children), and belongs to the obligations of a mayor (duties). Thus, the action of putting the issue of "swimming courses for parent and child" on the agenda of the next City Sports Committee session (health policy action) again follows the interplay of different internal and external determinants. However, in the policy action context, the categories derived from von Wright's model develop a more complex collective meaning. For example, it may well be that the mayor's intention to implement such swimming courses is backed by his personal want. But what usually is decisive for the progress of his intentions is the "politically wanted", e.g., what is good for the public in the municipality, or what is in line with the goals of his party or mandate. At the same time, a political intention can be pursued both by individual political representatives and by collective actors (e.g., parliamentary parties or organised interest groups). Thus, concrete policy actions usually are not simply determined by the personal wants of the policymakers, but by the wants of their organisations (e.g., parties, ministries, municipal authorities). Consequently, we use the term goals in this policy context, considering their formal characteristics (e.g., concreteness of goals) and their substantive attributes (e.g., service vs. health gain orientation). Similarly, in the policy context the concept of ability does not refer only to the individual abilities of the different actors, but to the organisational capacity and resources of both governmental and non-governmental entities involved. For example, the mayor's intention to implement the swimming courses may take into account that the municipal authorities are competent to get the sport clubs developing respective offers, thus utilising their resources for implementing the policy. Correspondingly the policy survey presented in the subsequent research paper focuses on resources, including capacities of the organisation the policymakers represent, e.g., in terms of personnel and financial resources, as well as other resources available and personal abilities of the policymaker.

With regard to the concept of duties, the context of health policy action is characterised by a specific set of obligations. These are not only related to the personal and professional duties of a mayor, but also to the institutional arrangements of the policy system, as well as to the community that is being effected by the policy. Among others, there are more formal obligations, e.g., related to national laws or inter national agreements, as well as obligations related to professional roles and personal commitment of the policymaker.

Opportunities, introduced above as a crucial starting point for processes of action, also show a specific pattern in policymaking processes. For example, opportunities can result internally from changes in both the organisation of the policymaker (e.g., new decision structures or actors) and externally in the political and inter-organisational settings (e.g., changes in the responsibilities of different political levels). Moreover, opportunities for health policy action may either increase or decrease corresponding to changes in public awareness, engagement of the population, and mass media interest.

\section{Connection between action levels}

As the ultimate goal of health promotion policy is health gain of the population, the effectiveness of such policy is very much related to a process of co-production of policymaking (including implementation) and policy-related behaviour of the population. Thus, key issues of health promotion policy implementation analysis and evaluation should refer to both levels; i.e., the investigation of major determinants of health promotion policy impact in terms of policy output and outcomes as well as to major determinants of participation in health promotion action at the population level (for the latter, see Rütten, von Lengerke et al. 2000; Rütten et al. 2001).

For the purpose of the present study, Figure 2 shows the connection between policy determinants and policy impact according to the theoretical framework. First, health policy, e.g., aiming at promoting physical activity of the population, must develop an "output", i.e., implement some measures, to be able to reach the population's health behaviour. However, policy output does not automatically mean health outcome on the population level. For example, mass media campaigns to promote physical activity in most controlled studies have failed in reaching a significant behavioural change (Hillsdon et al. 2001; Task Force on Community Preventive Services 2002). 
Rütten, A., Lüschen, G., Lengerke, T. von, Abel, T., Kannas, L., Rodrígue Diaz, J.A., Vinck, J., Zee, J. van der Determinants of health policy impact: a theoretical framework for policy analysis.

Sozial- und Präventivmedizin: 48, 2003, nr. 5, p. 293-300

The crucial point is whether the policy output creates an opportunity for the population to change their sedentary lifestyle. Thus, other policy measures such as environmental approaches to promote physical activity have been proven to be a more adequate strategy to reach intended behavioural changes - and, given the evidence of several health benefits of physical activity, will finally lead to a better health of the population (health outcomes).

\section{CONCLUSIONS}

In sum, the logic of events - a model which to the authors' knowledge has not been applied in social research so far - can be adopted for the analysis of health promotion policymaking. Moreover, its components represent a notion of determinism in policy processes that may be helpful to clarify in an analytic way structural elements of policy development and implementation (Lüschen 1992: 55). As will be shown in a subsequent research paper (Rütten et al. 2003), this form of policy analysis can assist in predicting both the likely implementation and the likely impact of policy. According to this empirical study, some of the policy determinants outlined above appear to be particular important for the health outcome of policies on the population level. For example, concrete goals, sufficient personal and financial resources and public support for a particular health promotion policy turn out to be significant predictors of achieved behaviour change on the population level. Other policy determinants appear to be especially related to policy implementation. For example, personal commitment of policymakers as well as certain organisational capacities turn out to be significant predictors of "policy output", e.g., of the variety of programs which were implemented.

The present model balances complexity and simplicity in a way which implies a great potential for the multidimensional and multidisciplinary field of health promotion. Given a strong need to elaborate the policy focus of health promotion, the model may be both appropriate and generally acceptable as a framework for policy analysis in this field (Rütten, Lüschen et al. 2000).

To conclude: some similar elements to those offered by von Wright either have been suggested by policy-related theories or have been found in previous policy research in health promotion. However, these elements rarely have been integrated in a consistent theoretical model of health policy action which can also be used as framework for international comparisons. In particular, the parsimony and generalisability of the present model as well as its clear assumptions on the nature and logical relationship of four key determinants of policy action makes it worthwhile to test its empirical evidence in a cross-national study (Rütten et al. 2003).

Research using this theory might lead to improved health outcomes across populations by evaluating the determinants of actual health promotion policies as well as by providing a concrete framework for developing future health policy. In particular, the analysis of determinants of certain policy orientations, e.g., output vs. outcome orientation as indicated above, may show ways how to support a shift from rather service-oriented concepts to health promotion approaches emphasising the health gain of the population.

\section{ACKNOWLEDGEMENTS}

This research was conducted within the MAREPS-project (Methodology for the Analysis of the Rationality and Effectiveness of Prevention and Health Promotion Strategies), a Concerted Action funded within the BIOMED 2-program by the European Union (European Commission, Brussels, Belgium; Contract N BMH4-CT96-0304; Contractor: Chemnitz University of Technology; Associated Contractors: Limburg University Centre [Diepenbeek, Belgium]; University of Jyväskylä [Jyväskylä, Finland]; Netherlands Institute of Primary Health Care [Utrecht, The Netherlands]; University of Valencia [Valencia, Spain], sub-contractor: University of Barcelona [Barcelona, Spain]; University of Berne [Berne, Switzerland]), and led by the Chemnitz University of Technology. Field work in MAREPS was supported by grants from: Ministry of the Flemish Community, Cabinet of the Flemish Minister of Finance, Budget and Health Policy (Brussels, Belgium); Ministry of Education and Ministry of Social Affairs and Health (both Helsinki, Finland); Saxon State Ministry of Social Affairs, Health and Family Affairs (Dresden, Germany); Health Research and Development Council ('s-Gravenhage, The Netherlands); Department of Home Affairs, Federal Office for Public Health and Federal Office for Education and Science (Berne, Switzerland). The authors would also like to thank Mark J. Schlesinger, Division of Health Policy and Administration, Yale University, for helpful 
Rütten, A., Lüschen, G., Lengerke, T. von, Abel, T., Kannas, L., Rodrígue Diaz, J.A., Vinck, J., Zee, J. van der Determinants of health policy impact: a theoretical framework for policy analysis.

Sozial- und Präventivmedizin: 48, 2003, nr. 5, p. 293-300

remarks on an earlier draft, and last but not least two anonymous reviewers for their very constructive comments on the preceding version of this paper.

\section{ZUSAMMENFASSUNG}

\section{Determinanten des Impacts von Gesundheitspolitik: ein theoretisches Rahmenmodell für die Policyanalyse}

Dieser Artikel behandelt die Rolle von Policy und Evidenz in der Gesundheitsförderung. Das von Wright-Konzept (1976) der „Logik der Ereignisse“ wird eingeführt und in einer Analyse des Impacts von Gesundheitspolitik angewendet. Gemäss von Wright (1976) kann das menschliche Handeln durch eine beschränkte Anzahl von Determinanten erklärt werden: Wünsche, Fähigkeiten, Pflichten, und Gelegenheiten. Die Dynamik von Handlungen resultiert dabei aus Veränderungen in den Gelegenheiten (Logik der Ereignisse). Angewendet auf den politischen Prozess erklärt das Modell persönliche Wünsche als den politischen Zielen untergeordnet. Fähigkeiten von einzelnen Politikern sind Teil von organisatorischen Ressourcen. Ebenso sind persönliche Pflichten sind ebenso den institutionellen Zielen untergeordnet. Gelegenheiten beziehen sich hauptsächlich auf den politischen Kontext und die öffentliche Unterstützung. Diese Analyse zeigt, dass Policydeterminanten wie konkrete Ziele, ausreichende Ressourcen und öffentliche Unterstützung ausschlaggebend für die Erreichung angestrebter Verhaltensänderungen auf Bevölkerungsebene sein könnten, andere Determinanten dagegen wie persönliches Verpflichtungsgefühl und organisatorisches Leistungsvermögen vor allem für policybezogene Implementierungsprozesse. Der Artikel schliesst mit einer Diskussion, wie künftige Forschung unter Verwendung des vorgestellten Rahmenmodells zur Praxis der Gesundheitsförderung und damit zu verbesserten Gesundheitseffekten auf der Ebene von Bevölkerungen beitragen könnte.

\section{RÉSUMÉ}

\section{Déterminants de l'impact d'une politique de santé: un cadre d'analyse théorique}

Cet article traite du rôle des données probantes pour la promotion de la santé. Le concept de "logique des événements”, développé par von Wright, est présenté et appliqué à une analyse d’impact d'une politique de santé. Selon von Wright (1976), les actions humaines peuvent être expliquées par un nombre limité de déterminants tels que la volonté, la capacité, le devoir et l’opportunité. Les dynamiques actionnelles sont le produit de changements d’opportunités (logique des événements). Appliqué au processus de décision politique, ce modèle explique que les volontés personnelles sont subordonnées aux objectifs politiques. Les capacités des décideurs politiques individuels font partie des ressources organisationnelles. De même, les devoirs personnels sont subordonnés aux obligations institutionnelles. Les opportunités sont avant tout en rapport avec le contexte politique et le soutien public. Notre analyse suggère que les déterminants de la politique de santé tels que des objectifs concrets, des ressources suffisantes et un soutien public peuvent être cruciaux pour obtenir des changements de comportement au niveau populationnel, alors que d'autres déterminants de la politique de santé, comme par exemple le dévouement personnel ou les capacités organisationnelles, peuvent avoir plus d'influence sur le processus d'implémentation d'une politique. Nous concluons l'article en indiquant des façons dont la recherche future peut contribuer à la promotion de la santé par l'amélioration des indicateurs de santé populationnels en utilisant ce cadre théorique. 
Rütten, A., Lüschen, G., Lengerke, T. von, Abel, T., Kannas, L., Rodrígue Diaz, J.A., Vinck, J., Zee, J. van der Determinants of health policy impact: a theoretical framework for policy analysis.

Sozial- und Präventivmedizin: 48, 2003, nr. 5, p. 293-300

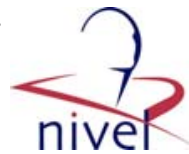

\section{FIGURES}

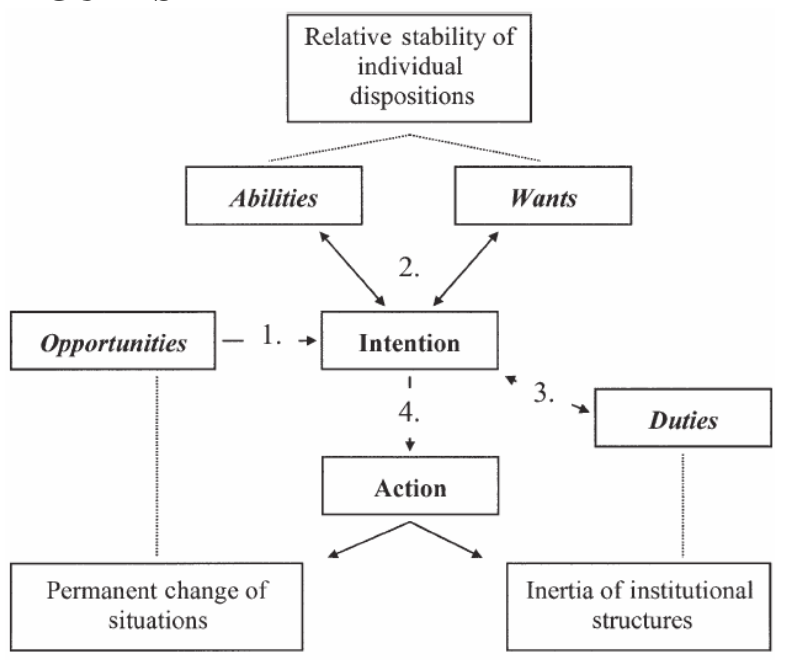

Figure 1 Logic of events, following von Wright (1976)

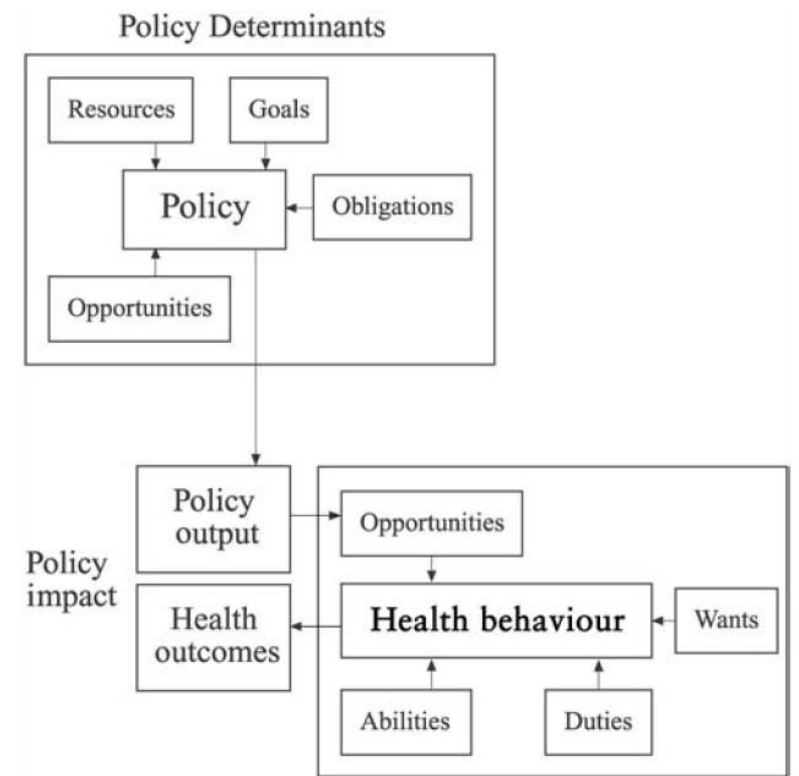

Figure 2 Logic of events: from policy determinants to health outcomes

\section{REFERENCES}

Advisory Committee on Cancer Prevention of the EU (2000).

Recommendations on cancer screening in the European Union. Eur J Cancer 36: 1473-8.

Alber J, BernardiSchenkluhn B (1992). Westeuropäische Gesundheitssysteme im Vergleich: Bundesrepublik Deutschland, Schweiz, Frankreich, Italien, Grossbritannien. Frankfurt a. M.: Campus.

Brownson RC, Koffman DM, Novotny TE, Hughes RG, Eriksen MP (1995). Environmental and policy interventions to control tobacco use and prevent cardiovascular disease. Health Educ Q 22: 47898.

Chen H-T (1990). Theorydriven evaluations. Newbury Park: Sage.

Cobb RW, Elder CD (1983). Participation in American politics: the dynamics of agenda-building.
Baltimore: The Johns Hopkins University Press.

Coleman JS (1990).

Foundations of social theory. Cambridge:

Belknap Press of Harvard University Press.

Dahrendorf R (1977). Homo sociologicus: ein Versuch zur Geschichte, Bedeutung und Kritik der Kategorie der sozialen Rolle. 15. Aufl. Opladen: Westdeutscher Verlag.

Dean, K (1996). Using theory to guide policy relevant health promotion research. Health Promot Int 11: 19-26.

Drummond MF, Jönsson $B$, Rutten $F$ (1997). The role of economic evaluation in the pricing and reimbursement of medicines. Health Policy 40: 199-215.

Drummond MF, O'Brien B, Stoddart GL, Torrance GW, eds. (1997). Methods for the economic evaluation of health care programmes. Oxford: Oxford University Press.

Esping-Andersen G (1990). The three worlds of welfare capitalism. Princeton: Princeton University Press.

Federal Statistical Office Germany (2002). Gesundheit: Ausgaben 1992 bis 2000.

Wiesbaden: Federal Statistical Office Germany.

Giddens A (1979). Central problems in social theory: action, structure and contradiction in social analysis. London: Macmillan.

Giddens A (1984). The constitution of society: outline of the theory of structuration. Cambridge: Polity.

Goumans M, Springett J (1997). From projects to policy: "Healthy Cities" as a mechanism for policy change for health? Health Promot Int 12: 311-22. 
Rütten, A., Lüschen, G., Lengerke, T. von, Abel, T., Kannas, L., Rodrígue Diaz, J.A., Vinck, J., Zee, J. van der Determinants of health policy impact: a theoretical framework for policy analysis. Sozial- und Präventivmedizin: 48, 2003, nr. 5, p. 293-300

Haddix A, Teutsch SM, Shaffer $P A$, Dunet DO, eds. (1996). Prevention effectiveness: a guide to decision analysis and economic evaluation. New York: Oxford University Press.

Hammer JS, Berman P (1995). Ends and means in public health policy in developing countries. Health Policy 32: 29-45.

Hillsdon M, Cavill N, Nanchahal K, Diamond A, White I (2001). National level promotion of physical activity: results from England's ACTIVE for LIFE campaign. J Epidemiol Commun Health 55: 755-61.

Kiser LL, Ostrom E (1982). The three worlds of action: a metatheoretical synthesis of institutional approaches. In: Ostrom, E, ed. Strategies of political inquiry. Beverly Hills: Sage: 179-222.

Kroneman MW, van der Zee $J$ (1997). Health policy as a fuzzy concept: methodological problems encountered when evaluating health policy reforms in an international perspective. Health Policy 40: 139-55.

de Leeuw E (1989). Health policy. Maastricht: University of Limburg: Doctoral dissertation.

de Leeuw E, Polman L (1995). Health policy making: the Dutch experience. Soc Sci Med 40: 331-8.

Lüschen G (1992). On logic, methodology and practice of applied sociology. Knowledge Policy 5: 5164.

Lüschen G (1995). Ein analytisches System für die Policy-Analyse und die angewandte Soziologie. In: Kreyher, VJ, Böhret, C, eds. Gesellschaft im Übergang.

Problemaufrisse und Antizipationen. BadenBaden: Nomos: 279-85.

Lüschen G, Cockerham W, van der Zee J, et al. (1995). Health systems in the European Union: diversity, convergence, and integration. München: Oldenbourg.

McQueen D (1996). The search for theory in health behaviour and health promotion. Health Promot Int 11: 27-32.

Melhaldo EM (1998). Economists, public provision, and the market: Changing values in policy debate. J Health Polit Policy Law 23: 215-63.

Milio N (1981). Promoting health through public policy. Philadelphia: F. A. Davis Company.

Milio N (1988). Strategies for health-promoting policy: a study of four national case studies. Health Promot 3: 307-11.

Milio N (1998). Priorities and strategies for promoting community-based prevention policies. J Public Health Manag Pract 4: 14-28.

Navarro V, Shi L (2001). The political context of social inequalities in health. Soc Sci Med 52: 481-91.

Nutbeam D (1998). Evaluating health promotion - progress, problems and solutions. Health Promot Int 13: 2744.

Pampel FC, Williamson JB (1989). Age, class, politics, and the welfare state. Cambridge: Cambridge University Press.
Phillips C (1997). Economic evaluation and health promotion. Aldershot: Avebury.

Reinhardt UE (1997). Making economic evaluations respectable. Soc Sci Med 45: 557-64.

Rootman I, Goodstadt M, Hyndman $B$, et al., eds. (2001). Evaluation in health promotion: principles and perspectives. Copenhagen: WHO Regional Office for Europe.

Rütten A (1995) The implementation of health promotion: a new structural perspective. Soc Sci Med 41: 1627-37.

Rütten A (2001). Evaluating healthy public policies in community and regional contexts. In: Rootman I, Goodstadt M, Hyndman B, et al., eds. Evaluation in health promotion: principles and perspectives. Copenhagen: WHO Regional Office for Europe: 341-63.

Rütten A, Abel T, Kannas L, et al. (2001). Self reported physical activity, public health, and perceived environment: results from a comparative study. J Epidemiol Commun Health 15: 35-47.

Rütten A, von Lengerke $T$, Abel T, et al. (2000). Policy, competence, and participation: empirical evidence for a multilevel health promotion model. Health Promot Int 15: 3547.

Rütten A, Lüschen $G$, von Lengerke $T$, et al. (2000). Health promotion policy in Europe: rationality, impact, and evaluation. München: Oldenbourg. 
Rütten, A., Lüschen, G., Lengerke, T. von, Abel, T., Kannas, L., Rodrígue Diaz, J.A., Vinck, J., Zee, J. van der Determinants of health policy impact: a theoretical framework for policy analysis.

Sozial- und Präventivmedizin: 48, 2003, nr. 5, p. 293-300

Rütten A, Lüschen $G$, von Lengerke $T$, et al. (2003). Determinants of health policy impact: comparative results of a European policymaker study. Soz Praventiv Med 48 (6) (in press).

Shapiro S, Coleman EA, Broeders M, et al. (1998). Breast cancer screening programmes in 22 countries: current policies, administration and guidelines. Int J Epidemiol 27: 735-42.

Sloan FA, Grabowski HG (1997). Introduction and overview. Soc Sci Med 45: 507-12.

de Swaan A (1988). In care of the state: health care, education and welfare in Europe and the USA in the modern era. Cambridge: Polity.

Task Force on Community Preventive Services (2002). Recommendations to increase physical activity in communities.
Am J Prev Med 22(4S): 67-72.

Weiss CH (1995). Nothing as practical as a good theory: exploring theorybased evaluation for comprehensive community initiatives for children and families. In: Connell JP, Kubisch AC, Schorr LB, Weiss $\mathrm{CH}$, eds. New approaches to evaluating community initiatives. Washington, DC: The Aspen Institute: 65-92.

Whitehead M (1996). The effectiveness of healthy public policies. In: Centre for Health Promotion, University of Toronto, ed. Healthy public policy. Toronto: Participaction.

Wilensky HL (1997). Social science and the public agenda: reflections on the relation of knowledge to policy in the United States and abroad. J Health Polit Policy Law 22: 1241-65.

World Health Organization (1986). Ottawa Charter for
Health Promotion. Ottawa: WHO.

World Health Organization (1998). Guidelines for controlling and monitoring the tobacco epidemic. Geneva: WHO.

von Wright GH (1976). Determinism and the study of man. In: Manninen J, Tuomela R, eds. Essays on explanation and understanding. Dordrecht: Deidel: 415-35.

Ziglio E, Hagard S, Levin LS (2001). Investment for health: developing a multifaceted appraisal approach. In: Rootman I, Goodstadt M, Hyndman B, et al., eds. Evaluation in health promotion: principles and perspectives. Copenhagen: WHO Regional Office for Europe: 493-513.

\author{
Address for correspondence \\ Prof. Dr. Alfred Rütten \\ Friedrich-Alexander-University of Erlangen-Nuremberg \\ Institute for Sport Sciences \\ Gebbertstr. 123b \\ D-91058 Erlangen \\ Tel.: +49 $913185-25000$ \\ Fax: +49 9131 85-25002 \\ e-mail: alfred.ruetten@sport.uni-erlangen.de
}

